\title{
Silicon Release from Local Materials in Indonesia under Submerged Condition
}

\author{
Linca Anggria ${ }^{1,2}$, Husnain $^{2}$, Kuniaki Sato ${ }^{1} \&$ Tsugiyuki Masunaga ${ }^{1}$ \\ ${ }^{1}$ Faculty of Life and Environmental Science, Shimane University, Matsue, Japan \\ ${ }^{2}$ Indonesian Soil Research Institute, Bogor, Indonesia \\ Correspondence: Tsugiyuki Masunaga, Faculty of Life and Environmental Science, Shimane University, 1060 \\ Nishikawatsu, Matsue, Shimane 690-8504, Japan. Tel: 81-852-32-6066. E-mail: masunaga@life.shimane-u.ac.jp
}

\author{
Received: August 25, $2016 \quad$ Accepted: October 10, $2016 \quad$ Online Published: November 15, 2016 \\ doi:10.5539/jas.v8n12p72 URL: http://dx.doi.org/10.5539/jas.v8n12p72
}

\begin{abstract}
Five inorganic materials (steel slag, silica gel, electric furnace slag, fly ash and Japanese silica fertilizer) and six organic materials (rice husk-biochar, rice straw compost, media of mushroom, cacao shell-biochar, rice husk-ash and elephant grass), were evaluated as Si fertilizer sources for rice plants (Oryza sativa L.) in two soil types (red clayey and sandy soil). Evaluation was carried out by incubating them at $30^{\circ} \mathrm{C}$ under submerged condition for 70 days. The soil solution was replaced at day 7, 14, 21, 42, 49, 56, 63 and 70 and the amount of silicon (Si) release, $\mathrm{pH}$, Eh, calcium $(\mathrm{Ca})$, magnesium $(\mathrm{Mg})$, iron $(\mathrm{Fe})$ and manganese $(\mathrm{Mn})$ concentrations in soil solutions were determined. The amount of Si release ranged from n.d. (not detected)-32444.7 $\mathrm{mg} \mathrm{Si} \mathrm{kg}^{-1}$ and 105.84-48524.0 mg $\mathrm{Si} \mathrm{kg}{ }^{-1}$ in red clayey and sandy soil solutions, respectively during 70 days of incubation. Reduction in soil Eh was accompanied with an increase in the solubility of the soil Si especially for silica gel, electric furnace slag, elephant grass and media of mushroom. Higher exchangeable $\mathrm{Ca}$ content in soil tended to suppress Si release from rice straw compost, rice husk-ash and cacao shell-biochar. Considering the results of present study and availability of the materials, we concluded that steel slag of the inorganic materials and rice straw/husk and cacao shell-biochar of organic materials had the highest potential as Si fertilizer source in Indonesia.
\end{abstract}

Keywords: inorganic material, organic material, coexisting element, solubility

\section{Introduction}

Silicon is not recognized as an essential element, but as a beneficial element, Si enhances diseases resistance, alleviates metal toxicity, improves nutrient balance, prevents lodging and enhanced drought tolerance of rice (Ma \& Yamaji, 2006). Silicate minerals liberate dissolved $\mathrm{Si}$ (DSi) as monosilicic acid $\left(\mathrm{H}_{4} \mathrm{SiO}_{4}\right)$ by chemical weathering (Cornelis et al., 2011). Furthermore, $\mathrm{Si}$ is taken up by the roots in the form of $\mathrm{H}_{4} \mathrm{SiO}_{4}$ (Ma \& Yamaji, 2006). However, the soluble Si content of tropical soils, such as highly weathered mineral (Ultisols and Oxisols) is generally less than that in most temperate soils as a result of Si leaching (Foy, 1992). While desilification and fertilization processes are extremely active in red soil (Liang et al., 2015). However, in sandy soil that consists mostly of quartz $\left(\mathrm{SiO}_{2}\right)$, the chemical decomposition of this mineral is complex (Marafon \& Endres, 2013). One of the most important factors that influence the solubility of $\mathrm{Si}$ in soil is redox potential. Low soil Eh as flooding condition, normally leads to an increase in available Si concentration (Liang et al., 2015). The solubility of Si containing mineral is affected by $\mathrm{pH}$, where the soil $\mathrm{pH}$ regulates the solubility and the mobility of $\mathrm{Si}$ (Tubana \& Heckman, 2015). Silica concentration is lowest at pH 8-9 and Si concentration in soil solution may rise sharply when $\mathrm{pH}$ value decreases from 7 to 2 (Beckwith \& Reeve, 1963).

Most of the land in Indonesia is acidic due to high level of leaching of basic cations. There is around $102,000,000$ ha of acidic soil with Ultisols and Oxisols are the dominant soil beside Entisols, Inceptisols and Spodosols (Subagyo et al., 2000; Mulyani et al., 2009). These soils have been used for rice production in Indonesia. Although $\mathrm{Si}$ is very abundant element in soil with the range from 25 to $35 \%$, repeated cropping can reduce the levels of plant-available Si to the point that supplemental Si fertilization is required for maximum production (Datnoff \& Rodrigues, 2005). In Indonesia, lower soil Si content was found to be severe in intensive rice field where enormous Si uptake is not followed by sufficient Si replenishment (Husnain et al., 2008). In present, the most common forms of silicate materials used as fertilizer are various industrial by products (Haynes, 2014). Slag from iron and alloy manufacturing that consist of calcium silicate which could be used to meet the 
demand of Si. Fly ash from coal combustion where the dust-collection system removes the fly ash from the combustion gases before they are discharged in the atmosphere is high in Si content (Ramezanianpour, 2014). These Si rich materials from industrial wastes are also applied to increase soil pH (Haynes et al., 2013).

Besides industrial wastes, potential organic sources of silicate material have been assessed for use as an agricultural amendment. As plants accumulate $\mathrm{Si}$, there is possibility of using crop residues as $\mathrm{Si}$ source. For example, rice (Oryza sativa L.) husk and sugarcane (Saccarum spp.) bagasse have considerable Si concentration (Gascho, 2001). Biogenic amorphous silica is a natural constituent from unicellular organism, compost and crop residue (Rabovsky, 1995; Tubana \& Heckman, 2015). However, the demand of Si from crop residues for agriculture is insufficient from plant residues. To address this issue, it is desirable to explore cheap and abundant local materials as Si source.

In Indonesia, there are some potential sources as silicate fertilizer from industrial by product and plant material-based silica. Factories that produce slag as by product of steel with crude steel production was 4.7 million ton on 2011 (Ministry of Industry Republic of Indonesia, 2014). Production of coal in Indonesia is around 437 million ton (Outlook Energy Indonesia, 2014) with fly and bottom ash as waste. Indonesia is the world's third largest cocoa bean producer (FAO, 2010) so it is also possible to use cacao shell and leaf as source of $\mathrm{Si}$ fertilizer. Considering the large amount of $\mathrm{Si}$ accumulated in rice straw and husk, straw compost and husk burning are an interesting Si source for plants.

Emphasis should be made not only on Si content but also on its solubility. The release of Si from the local materials into soil solution varies in different combination of materials and soils. Factors controlling dissolution of $\mathrm{Si}$ include iron $(\mathrm{Fe})$, calcium $(\mathrm{Ca})$, manganese $(\mathrm{Mn}), \mathrm{pH}$, particle size of the materials and presence of organic matter (Makabe et al., 2013; Kendrick, 2006). The factors that cause variation Si release from material and soil should be evaluated to improve use of material as Si source. Therefore, the objective of this study is to evaluate Si release from different local materials used as soil fertilizers under submerged conditions in relation with soil chemical properties and other controlling factors.

\section{Materials and Methods}

The Si release from the local materials was characterized through laboratory incubation experiments.

\subsection{Si Source Materials}

Eleven materials were collected from Indonesia and Japan. There are two groups of materials, namely (1) five inorganic materials (fly ash from coal company in South Sumatera, steel and electric furnace slag/EFS were obtained from Banten, silica gel, Japanese silica fertilizer (JSF) is a slag-based silicate fertilizer). (2) Six organic materials (elephant grass (Pennisetum purpureum), rice (Oryza sativa L.) straw compost/RSC, rice husk-biochar/RHB, cacao (Theobroma cacao L.) shell-biochar (cacao SB), media of mushroom/MM and rice husk-ash/RHA from West Java. The geographic and climatic condition of South Sumatera is $1{ }^{\circ} 0^{\prime}-4^{\circ} 0^{\prime} \mathrm{S}$ and $102^{\circ} 0^{\prime}-106^{\circ} 0^{\prime} \mathrm{E}$ (Badan Pusat Statistik (BPS), 2015), Banten is $5^{\circ} 7^{\prime} 50^{\prime \prime}-7^{\circ} 1^{\prime} 1^{\prime \prime} \mathrm{S}$ and $105^{\circ} 1^{\prime} 11^{\prime \prime}-106^{\circ} 7^{\prime} 12^{\prime \prime} \mathrm{E}$ (Banten, 2016). West Java is $5^{\circ} 50^{\prime}-7^{\circ} 50^{\prime} \mathrm{S}$ and $104^{\circ} 48^{\prime}-108^{\circ} 48^{\prime} \mathrm{E}$ (Jawa Barat, 2016), with rainfall of about 3409,3573 and $2682 \mathrm{~mm}$ on 2013 in South Sumatera, Banten and West Java, respectively (Badan Meteorologi Klimatologi dan Geofisika (BMKG), 2000-2013). The elephant grass and media of mushroom were air-dried for 2-3 days. Materials were ground into fine powder in agate grinding jars, using a mixer mill (MM 200, Retsch GmbH, Haan, Germany).

Samples were oven-dried 12 hours at $80^{\circ} \mathrm{C}$. Total element (Ca, Mg, K, Na, Fe Mn, Cu, $\mathrm{Zn}, \mathrm{Cd}$ and $\mathrm{Ni}$ ) composition of materials was measured by ICP after digestion in Teflon vessel with $\mathrm{HNO}_{3}$ at $160^{\circ} \mathrm{C}$ for 4 hours and diluted with distilled water up to $25 \mathrm{ml}$ after kept resting overnight (Koyama \& Sutoh, 1987). Total carbon (C) was assessed using dry combustion methods (Sumigraph NC-22 Analyzer).

Available Si (Table 1) was extracted from materials with $0.5 \mathrm{M} \mathrm{HCl}$ (1: 150 ratio for $1 \mathrm{~h}$ shake at $110 \mathrm{rpm}$ ) (Savant el al., 1999) and $\mathrm{Na}_{2} \mathrm{CO}_{3} / \mathrm{NH}_{4} \mathrm{NO}_{3}\left(10 \mathrm{~g} \mathrm{~L}^{-1} / 16 \mathrm{~g} \mathrm{~L}^{-1}\right)$ (1:100 ratio for $1 \mathrm{~h}$ shake at $\left.110 \mathrm{rpm}\right)$ (Pereira et al., 2003). The concentration of $\mathrm{Si}$ in all extracts was determined using the molybdenum blue method and measured by Spectrophotometry UV 1800 Shimadzu. The wavelength use for the Si detection was $810 \mathrm{~nm}$. pH $\left(\mathrm{H}_{2} \mathrm{O}\right)$ was determined on 1: $30(\mathrm{w} / \mathrm{v})$ soil: water suspensions with $\mathrm{pH}$ meter (D-51, Horiba).

\subsection{Soil Samples}

Two types of soil were used, a red clayey soil (Ultisol) and a sandy soil (Entisol) with textural classes of clay loam and fine sand, respectively. Red clayey soil is slightly acidic $(\mathrm{pH} 5.7)$ and relatively rich in available $\mathrm{Fe}$ and $\mathrm{Mn}\left(72.5\right.$ and $52.2 \mathrm{mg} \mathrm{kg}^{-1}$ ). Exchangeable $\mathrm{Ca}$ and $\mathrm{Mg}$ were 4.3 and $2.4 \mathrm{cmol}_{\mathrm{c}} \mathrm{kg}^{-1}$, respectively. Sandy soil is neutral in $\mathrm{pH}$ (7.3), has high content of exchangeable $\mathrm{Ca}\left(26.4 \mathrm{cmol}_{\mathrm{c}} \mathrm{kg}^{-1}, 1 \mathrm{M}\right.$ ammonium acetate extractable $\left.\mathrm{Ca}\right)$ 
and available $\mathrm{Fe}\left(136.4 \mathrm{mg} \mathrm{kg}^{-1}\right)$. The available Si concentration of red clayey and sandy soil was 267.1 and $129.3 \mathrm{mg} \mathrm{SiO}_{2} \mathrm{~kg}^{-1}$, respectively. According to Sumida (1992), those were classified to be below critical level of available silica for rice $\left(300 \mathrm{mg} \mathrm{SiO} \mathrm{kg}^{-1}\right)$. We expected the difference of these properties to influence the dynamics of dissolved Si from the local materials.

The soil sample was air dried and passed through a $2 \mathrm{~mm}$ sieve. Exchangeable $\mathrm{Ca}$ and $\mathrm{Mg}$ were extracted with 1 M ammonium acetate pH 7.0 and measured by Inductive Coupled Plasma Spectroscopy (ICPE-9000 Shimadzu, Kyoto Japan). Available Si was extracted by acetate buffer $\mathrm{pH} 4$ with ratio of 1:10, for intermittent shaking for $5 \mathrm{~h}$ at $40{ }^{\circ} \mathrm{C}$, determined using the silicate molybdenum blue method (Imaizumi \& Yoshida, 1958). Soil pH $\left(\mathrm{H}_{2} \mathrm{O}\right)$ was determined on 1:2.5 (w/v) soil: water suspensions with $\mathrm{pH}$ meter (D-51, Horiba). The contents of available $\mathrm{Fe}$ and $\mathrm{Mn}$ were obtained by extraction with $0.1 \mathrm{~N} \mathrm{HCl}$ and quantified using the ICP.

\subsection{Incubation Experiment}

Under submerged condition, the soil was incubated with Si materials as treatment. The experiment was replicated three times. Air dried soil of $10 \mathrm{~g}$ was placed in a $50 \mathrm{~mL}$ centrifuge plastic tube, $1 \mathrm{~g}$ of organic material and $40 \mathrm{~mL}$ of distilled water were added into the tube. For inorganic material (steel slag, fly ash, EFS and JSF) $0.02 \mathrm{~g}$ of $30 \% 0.5 \mathrm{M} \mathrm{HCl}$ and silica gel $0.02 \mathrm{~g}$ of $30 \% \mathrm{Na}_{2} \mathrm{CO}_{3} / \mathrm{NH}_{4} \mathrm{NO}_{3}$ as silicon dioxide $\left(\mathrm{SiO}_{2}\right)$ were added to the centrifuge tube containing $10 \mathrm{~g}$ of soil, and then $40 \mathrm{~mL}$ of distilled water was added. The tube was covered and mixed thoroughly, incubated at $30^{\circ} \mathrm{C}$ for 70 days. After incubation, the redox potential (Eh) and $\mathrm{pH}$ of soil solution were measured with Eh meter and pH meter (TOA HM-14P and D-51 Horiba, respectively) without disturb the soil. The supernatant was obtained after filtration (paper filter Advantec No. 6). Silica, Ca, $\mathrm{Mg}, \mathrm{Fe}$ and $\mathrm{Mn}$ concentrations in supernatant were measured using ICPE-9000 Shimadzu. To resume the incubation, residue on the filter paper was washed back into tube with distilled water and distilled water was added up to a total volume of $40 \mathrm{~mL}$ base on the weight (Makabe et al., 2013). The soil solution was replaced with distilled water at day (d) 7, 14, 21, 42, 49, 56, 63 and 70 assuming field water replacement by drainage / leaching and irrigation in the field.

\subsection{Data Analysis}

The release of $\mathrm{Si}$ in the soil solution after the incubation experiment is symbolized the concentration of $\mathrm{Si}(\mathrm{mmol}$ $\left.\mathrm{L}^{-1}\right)$. The net release of $\mathrm{Si}$ and the other elements $(\Delta \mathrm{Si}, \Delta \mathrm{Ca}, \Delta \mathrm{Fe}, \Delta \mathrm{Mg}, \Delta \mathrm{Mn})$ from the materials was estimated based on the difference between the concentration of elements in samples with materials and without material (control). A correlation analysis was conducted to identify relationship between the $\mathrm{Si}$ and other elements. Statistical analyses were done using the statistical package SPSS 22.

\section{Results and Discussion}

\subsection{Chemical Composition of Si Material Sources}

The chemical composition of 11 materials used in this study is shown in Table 1. 
Table 1. Chemical composition of materials

\begin{tabular}{|c|c|c|c|c|c|c|c|c|c|c|c|c|}
\hline \multirow{2}{*}{ Material } & \multirow{2}{*}{$\mathrm{pH}$} & \multicolumn{2}{|c|}{$\mathrm{Si}$} & \multirow{2}{*}{$\mathrm{TC}$} & \multirow{2}{*}{$\mathrm{Ca}$} & \multirow{2}{*}{$\mathrm{Mg}$} & \multirow{2}{*}{$\mathrm{Fe}$} & \multirow{2}{*}{$\mathrm{Mn}$} & \multirow{2}{*}{$\mathrm{Cu}$} & \multirow{2}{*}{$\mathrm{Zn}$} & \multirow{2}{*}{$\mathrm{Cd}$} & \multirow{2}{*}{$\mathrm{Ni}$} \\
\hline & & $\mathrm{Na}_{2} \mathrm{CO}_{3} / \mathrm{NH}_{4} \mathrm{NO}_{3}$ & $\mathrm{HCl} 0.5 \mathrm{M}$ & & & & & & & & & \\
\hline & & \multicolumn{2}{|c|}{------------ $\mathrm{mmol} \mathrm{kg}^{-1}$} & \multicolumn{9}{|c|}{ - } \\
\hline Steel slag & 9.8 & 5.2 & 801.0 & 1400 & 198105.2 & 34818.5 & 281649.6 & 9605.1 & 147.1 & 46.1 & 67 & 113.6 \\
\hline Silica gel & 6.8 & 234.3 & 96.6 & - & 11013.9 & 3283.6 & 6124.5 & 102.9 & - & - & - & - \\
\hline Fly ash & 7.7 & 28.3 & 300.1 & 107802.6 & 18368.1 & 9006.0 & 29612.9 & 341.9 & 30.7 & 102.3 & 18.4 & 47.2 \\
\hline EFS & 9.5 & 4.7 & 412.5 & 7700.0 & 157214.1 & 59459.2 & 151671.3 & 11589.5 & 120.9 & 942.3 & 56.4 & 109.9 \\
\hline JSF & 12.4 & 137.1 & 975.0 & 20259.0 & 240126.9 & 18261.8 & 8606.2 & 23003.8 & - & - & - & - \\
\hline $\mathrm{RSC}$ & 9.5 & 74.3 & 44.0 & 222578.3 & 14364.9 & 4340.8 & 16297.7 & 1833.5 & 26.6 & 87.8 & 9.7 & 18.7 \\
\hline RHB & 7.6 & 56.5 & 2.8 & 427394.4 & 1952.0 & 991.5 & 2489.0 & 552.5 & 3.8 & 38.7 & 1.6 & 4.3 \\
\hline RHA & 10.7 & 98.8 & 10.3 & 3650.4 & 3429.4 & 793.3 & 372.6 & 592.5 & 2.2 & 38.1 & 1.1 & 3.5 \\
\hline Cacao SB & 10.5 & 5.7 & 133.5 & 423490.9 & 22278.9 & 15601.3 & 4189.9 & 1198.3 & 54.4 & 317.9 & 8.1 & 27.6 \\
\hline Elephant grass & 5.2 & 192.1 & 5.4 & 427055.8 & 6043.3 & 2528.2 & 216.8 & 59.9 & 6.2 & 35.5 & 1.4 & 7.2 \\
\hline MM & 8.6 & 52.5 & 2.6 & 360115.7 & 76687.3 & 2692.8 & 1594.9 & 246.3 & 6.8 & 27 & 6.8 & 15.2 \\
\hline
\end{tabular}

Note. -: not determined, TC: total carbon, EFS: electric furnace slag, JSF: Japanese Si fertilizer, RSC: rice straw compost, RHB: rice husk-biochar, RHA: rice husk-ash, cacao SB: cacao shell-biochar, MM: media of mushroom.

Inorganic materials were alkaline in nature with JSF having the highest $\mathrm{pH}$, except silica gel. According to Savant et al. (1997), the amount of $\mathrm{H}_{4} \mathrm{SiO}_{4}$ in soil solution is affected by $\mathrm{pH}$ and the soil $\mathrm{pH}$ regulates the solubility and the mobility of $\mathrm{Si}$ (Tubana \& Heckman, 2015). Among the elements, $\mathrm{Ca}, \mathrm{Mg}, \mathrm{Mn}$ and $\mathrm{Fe}$ were reported to relate to soil Si availability (Makabe et al., 2013; Hansen et al., 1994). Among all the materials used, JSF had highest $\mathrm{Ca}$ and $\mathrm{Mn}$ content. The highest $\mathrm{Fe}$ and $\mathrm{Mg}$ content were found in steel slag and $\mathrm{EFS}$, as chemical composition of EFS was $\mathrm{CaSiO}_{3} / \mathrm{MgSiO}_{3}$, while steel slug was $\mathrm{CaSiO}_{3}$ (Tubana \& Heckman, 2015). The lowest $\mathrm{Ca}, \mathrm{Mn}, \mathrm{Mg}$ and $\mathrm{Fe}$ content were found in silica gel.

The chemical composition of organic materials indicated that RHA had the highest $\mathrm{pH}$ (10.7) and elephant grass had the lowest (5.2). Carbon content in organic materials ranged from 222578.3 to $427394.4 \mathrm{mg} \mathrm{kg}^{-1}$, except RHA material. MM had higher Ca content than the other organic materials because in mushroom cultivation, the media was added with $\mathrm{CaCO}_{3}$ to neutralize acid that was released by mushroom. Cacao SB had high content of $\mathrm{Mg}\left(15601.3 \mathrm{mg} \mathrm{kg}^{-1}\right)$. RSC compost had the highest Fe and $\mathrm{Mn}$ and the lowest was elephant grass. Among materials, except JSF as reference, the available Si content was highest in steel slag.

Concentration of $\mathrm{Si}$ was higher with $0.5 \mathrm{M} \mathrm{HCl}$ than $\mathrm{Na}_{2} \mathrm{CO}_{3} / \mathrm{NH}_{4} \mathrm{NO}_{3}$ (alkaline) solution for inorganic materials (300.1-975.0 mmol $\mathrm{Si} \mathrm{kg}^{-1}$ ), except silica gel. For organic material, $\mathrm{Si}$ concentration was high with $\mathrm{Na}_{2} \mathrm{CO}_{3} / \mathrm{NH}_{4} \mathrm{NO}_{3}$ solution (52.5-192.1 mmol Si kg ${ }^{-1}$ ), except cacao $\mathrm{SB}$.

Concerning about heavy metal pollution by material application, $\mathrm{Cu}, \mathrm{Zn}, \mathrm{Cd}$ and $\mathrm{Ni}$ contents of all the materials were below the regulatory limit of Environmental Protection Agency (EPA) (1993); $\mathrm{Cu}=4300, \mathrm{Zn}=7500, \mathrm{Cd}=$ 85 , and $\mathrm{Ni}=420 \mathrm{mg} \mathrm{kg}^{-1}$.

\subsection{Release Pattern of Si from Materials (4 Si) for 70 Days Incubation}

The temporal changes in Si concentrations in the soil solution show that Si release rate and pattern for soil and materials differed. The Si release pattern was different between two type of soil and eleven materials. Release of $\mathrm{Si}$ from the materials in red clayey soil during 70 days of incubation is shown in figure 1a. Concentration of Si in soil solution from silica gel was stable and reached different peaks 42-56 days after flooding. Silica release from steel slag in red clayey soil started after day 49 and then increased rapidly until the end of incubation. It may indicate continuous dissolution of Si from steel slag. The dissolution pattern of Si from steel slag was different to dissolution pattern of silicate slag fertilizer reported by Makabe et al. (2013), where Si dissolution increased rapidly during the first 22 days in weakly acidic solution.

In contrast, fly ash released $\mathrm{Si}$ on the first 49 days then remained not detected (n.d.). A slightly higher peak of Si release from silica gel and fly ash at day 42 was probably because the soil solution was not changed for three weeks after day 21, this condition resulted in high Si in soil solution. Meanwhile, EFS and JSF did not apparently release Si throughout the incubation period in red soil. It was probably that the bond between Si and 
the other elements such as Fe-O-Si, $\mathrm{CaO}-\mathrm{SiO}_{2}-\mathrm{H}_{2} \mathrm{O}$ (Hansen et al., 1994; Flint \& Wells, 1934) in these materials was too strong to release $\mathrm{Si}$ in the red soil incubation condition.
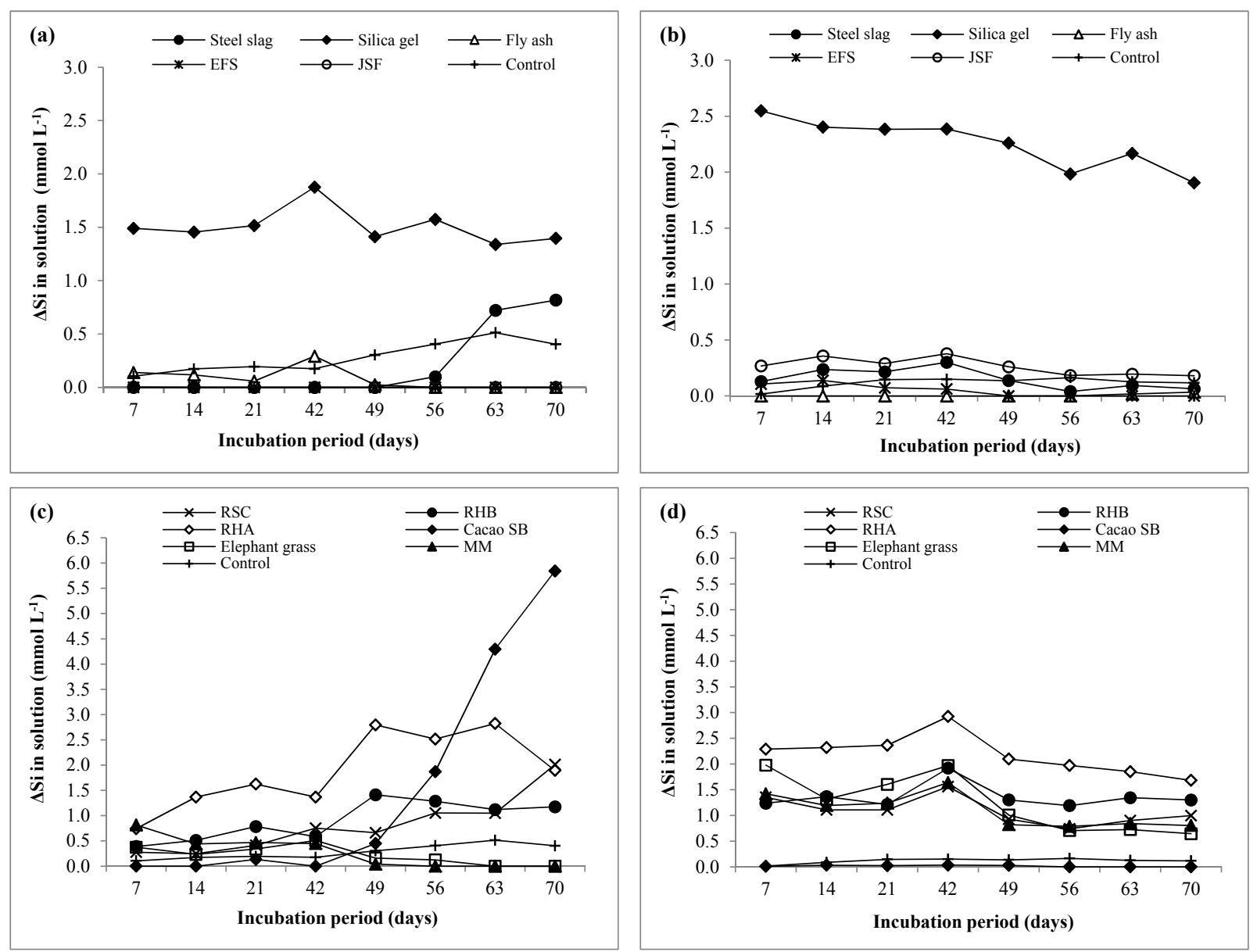

Figure 1. Release pattern of Si from the materials $(\Delta \mathrm{Si})$ : (a) red clayey and (b) sandy soils with inorganic materials; (c) red clayey and (d) sandy soils with organic materials

Figure 1c shows release of Si from organic materials in red clayey soil. Silica concentration in soil solution with added RSC tend to increase as incubation period increased. Release of Si from RHB and RHA had similar

pattern, where the release of Si was started from day 7. Silica release from cacao SB started on day 21 up to the end of incubation time. Release of Si from MM is described by an initially fast release on day 7 followed by a progressively slight release until 42 days of incubation. Silica release rates from elephant grass tended to be slightly higher on 56 days of incubation.

The effect of EFS application gradually becomes less pronounced and not detected toward the end of experiment in sandy soil (Figure 1b). Concentration of $\mathrm{Si}$ in sandy soil with steel slag application increased during first weeks of incubation time. Silica concentration reached the maximum value after 42 days of incubation and then gradually decreased. Silica release from JSF was high during first 49 days, then decreased. The rate of Si concentration from silica gel decrease with the time of incubation. We recorded that Si release from fly ash in sandy soil solution was less (n.d.-0.03 $\mathrm{mmol} \mathrm{L}^{-1}$ ) than red clayey soil, which Si release was only during the last 14 days of incubation.

Si release from silica gel was higher in sandy soil than red clayey soil. As silica gel is made by neutralizing water glass. Thus, according to Bunker et al. (1988) that the tetrahedral $\mathrm{SiO}_{4}$ sites common to all silicates glasses were susceptible to nucleophilic attack primarily by $\mathrm{OH}^{-}$to form a reactive five-coordinated intermediate which can be decomposed to rupture the Si-O-Si bond. Therefore, a significant quantity of $\mathrm{OH}^{-}$could improve the 
formation of a five-coordinated intermediate which could lead to a great dissolution of the silica gel. Moreover, as $\mathrm{Si}$ concentration was higher with alkaline solution (Table 1).

Figure 1d show release of Si from organic material in sandy soil solution. Silica release from RSC and MM had similar rate, where Si concentration in sandy soil solution was high in the first 42 days of incubation. Slightly different with RSC and MM, Si release was high for 49 days after submerged with added cacao SB and elephant grass. Silica release rates from RHB were fluctuating, with the highest Si concentration on day $42(1.92 \mathrm{mmol} \mathrm{Si}$ $\mathrm{L}^{-1}$ ). The fact that Si release from RHA was highest on day 42, then decreased until the end of incubation.

\subsection{The Amounts of Si Release and Coexisting Element from the Materials for 70 Days Incubation}

The cumulative amounts of $\mathrm{Si}$ and the element expected interact on with Si release from materials during the 70 days of incubation are listed in Table 2.

Table 2. Silicon and other elements release from materials and soil during 70 days.

\begin{tabular}{|c|c|c|c|c|c|c|c|c|c|c|}
\hline \multirow{2}{*}{ Materials or soil } & \multicolumn{5}{|c|}{ Red clayey soil } & \multicolumn{5}{|c|}{ Sandy soil } \\
\hline & $\mathrm{Si}$ & $\mathrm{Ca}$ & $\mathrm{Mg}$ & $\mathrm{Fe}$ & $\mathrm{Mn}$ & $\mathrm{Si}$ & $\mathrm{Ca}$ & $\mathrm{Mg}$ & $\mathrm{Fe}$ & $\mathrm{Mn}$ \\
\hline & \multicolumn{5}{|c|}{ - - } & \multicolumn{5}{|c|}{------------------- mmol kg-1 } \\
\hline Steel slag & 508.32 & 377.43 & 126.72 & 80.15 & 0.20 & 375.97 & 196.65 & n.d & 0.15 & 0.77 \\
\hline Silica gel & 1158.74 & 3.34 & 10.67 & 20.63 & 2.79 & 1733.00 & 82.31 & 4.16 & 0.39 & 0.01 \\
\hline Fly ash & 79.33 & 185.16 & 77.80 & 0.06 & n.d. & 6.40 & 201.61 & 50.17 & 0.44 & n.d \\
\hline EFS & n.d. & 861.84 & 471.59 & 36.35 & 0.41 & 64.22 & 108.13 & n.d & 0.08 & 0.43 \\
\hline JSF & n.d. & 2050.13 & 340.69 & 0.82 & 2.09 & 852.50 & 2217.51 & n.d & n.d & 0.31 \\
\hline $\mathrm{RSC}$ & 280.88 & 192.04 & 124.31 & 37.44 & 25.72 & 377.73 & 208.35 & 169.49 & 4.01 & 9.83 \\
\hline RHB & 304.86 & 10.26 & 6.16 & 9.01 & 0.42 & 456.12 & 39.84 & 34.83 & 0.02 & 2.82 \\
\hline RHA & 611.29 & 21.47 & 28.97 & 8.68 & 0.55 & 706.72 & n.d & n.d & 0.22 & 0.49 \\
\hline Cacao SB & 659.98 & 52.48 & 129.25 & 11.26 & 1.84 & 6.61 & n.d & 63.24 & 0.30 & 0.20 \\
\hline Elephant grass & 77.59 & 321.31 & 208.95 & 269.13 & 77.24 & 442.99 & 1441.29 & 309.08 & 12.13 & 0.68 \\
\hline MM & 98.20 & 1527.00 & 226.20 & 28.28 & 42.77 & 388.21 & 1599.20 & 227.12 & 1.02 & 1.18 \\
\hline Soil & 9.66 & 0.80 & 0.63 & 0.91 & 0.03 & 3.78 & 9.50 & 5.59 & 0.18 & n.d \\
\hline
\end{tabular}

Note. n.d.: not detected, EFS: electric furnace slag, JSF: Japanese Si fertilizer, RSC: rice straw compost, RHB: rice husk-biochar, RHA: rice husk-ash, cacao SB: cacao shell-biochar, MM: media of mushroom.

The amount of Si release in red clayey and sandy soils ranged from n.d.-1158.74 mmol Si kg-1 and 3.78-1733.00 mmol Si kg ${ }^{-1}$, respectively. The highest Si release in both red clayey and sandy soil was silica gel. Release of Si from red clayey soil (control) was higher than sandy soil, while Si concentration from soil was lower compared to that in the materials.

According to Marxen et al. (2016), Si concentrations in the soil solution from rice straw increased only when the organic matrix surrounding the phytoliths was decomposed and the surface of the phytoliths became exposed to soil solution. The release of Si was higher from RHA than RHB due to higher available Si content in RHA (Table 1), beside that C content in RHB was higher than RHA. According to Xiao et al. (2014), C and Si form in biochar result in the mutual protection between $\mathrm{C}$ and $\mathrm{Si}$. Silica in biochar becomes difficult to dissolve, reflecting the protection of $\mathrm{Si}$ by $\mathrm{C}$.

Organic materials in this research were high in Si concentration with alkaline solution, except cacao SB, which was high in acid solution. The results were similar to the initial Si concentrations in organic materials (Table 1). It is possible that alkaline solution dissolves organic matter that covers $\mathrm{Si}$ and thus $\mathrm{Si}$ may release from organic matter. According to Molina (2014), alkaline solution dissolved protoplasmic and structural components from fresh organic tissues.

Release of $\mathrm{Ca}, \mathrm{Mg}, \mathrm{Mn}$ and Fe were different among the materials and two soil types. In red clayey soil, released amounts of Ca and Mg were the highest from JSF (2050.13 mmol kg-1) and EFS (471.59 $\left.\mathrm{mmol} \mathrm{kg}^{-1}\right)$, it might be due to high $\mathrm{Ca}$ content in both of materials (Table 1). While the lowest of $\mathrm{Ca}$ and $\mathrm{Mg}$ were silica gel and RHB (3.34 and $6.16 \mathrm{mmol} \mathrm{kg}^{-1}$, respectively) due to $\mathrm{Ca}$ and $\mathrm{Mg}$ content was low in both materials. The highest Fe and Mn were released from elephant grass (269.13 and $77.24 \mathrm{mmol} \mathrm{kg}^{-1}$, respectively). 
Calcium and Mg release from soil (red clayey soil) was lower than in the materials. Red clayey soil has lower Fe solubility compared to in the materials, except fly ash and JSF.

For sandy soil, Ca release was the highest with JSF application due to its high Ca content. Manganese release was the highest with RSC $\left(9.83 \mathrm{mmol} \mathrm{kg}^{-1}\right)$, while $\mathrm{Fe}$ and $\mathrm{Mg}$ release was the highest from elephant grass.

Calcium release was lower in soil (sandy soil) than in the materials, except RHA and cacao SB. The release of Mg from soil (sandy soil) was lower than in the materials, except steel slag, silica gel, EFS, JSF and RHA. Almost the same with $\mathrm{Mg}, \mathrm{Fe}$ concentration from sandy soil was also lower than materials, except steel slag, EFS and JSF. Furthermore, Mn concentration from materials was higher than sandy soil, except fly ash. Kato and Owa (1997) reported that the application of the slags increase the Ca concentration in soil solution.

Eight of eleven materials had higher Si release in sandy soil than red clayey soil. According to Dematte et al. (2011), the chemical decomposition of clay mineral is complex, which made sandy soils more responsive on $\mathrm{Si}$ release than red clayey soils to the material application.

\subsection{Effects of $\mathrm{pH}$ and Eh}

It is generally stated that $\mathrm{Si}$ availability depends on soil types (Wei et al., 1997). In detail, $\mathrm{pH}$, Eh and the type of coexisting metals influence the adsorption of monosilicic acid by oxides (Tubana \& Heckman, 2015; Liang et al., 2015).

The increase of $\mathrm{pH}$ and decrease of Eh (Table 3) in red clayey soil solution due to added of materials and also effect of submergence. In sandy soil solution, the trend of $\mathrm{pH}$ and Eh was different with red clayey soil solution. Steel slag, EFS, JSF, RHA and cacao SB tend to increase soil solution $\mathrm{pH}$. Where steel slag, EFS, JSF, cacao SB, elephant grass and MM decrease soil solution Eh.

Table 3. Mean $\mathrm{pH}$ and Eh values of red clayey and sandy soil solution during 70 days of incubation

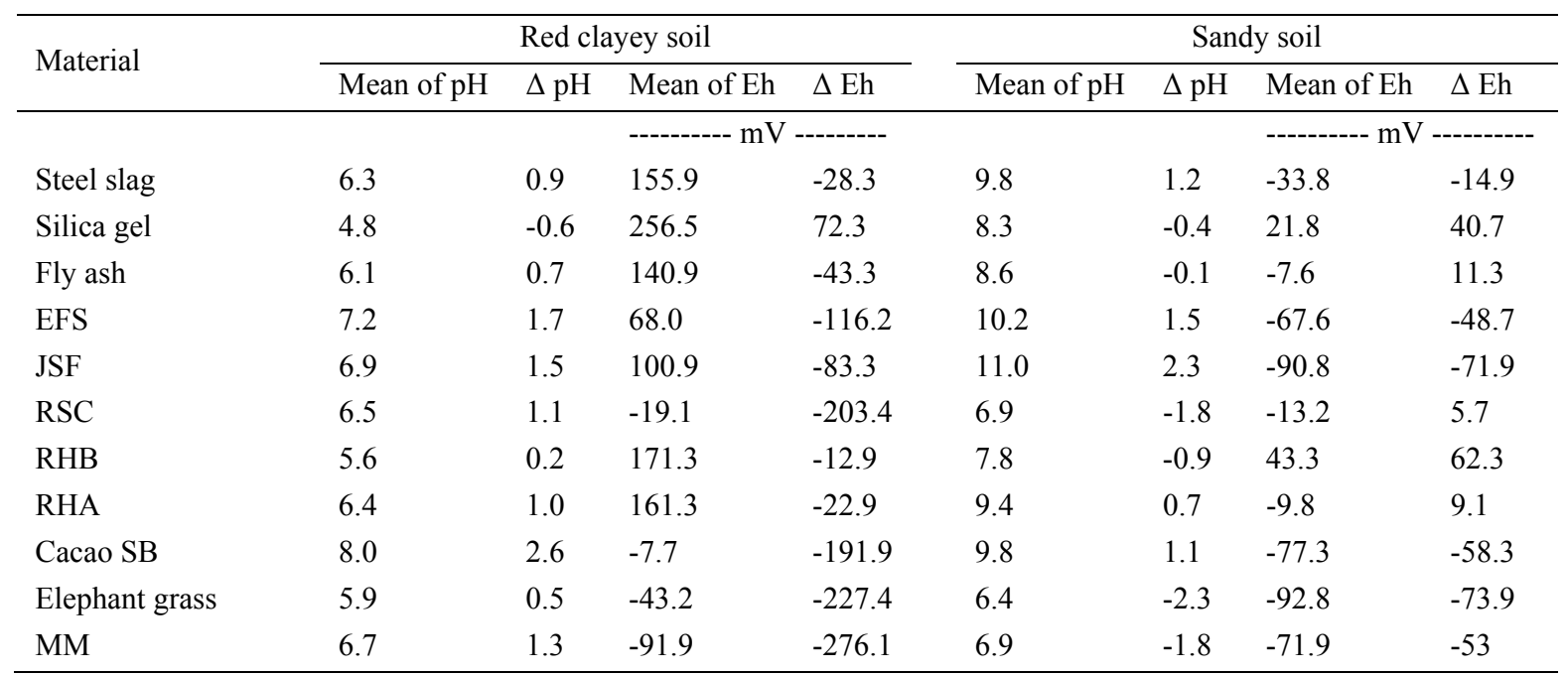

Note. $\Delta \mathrm{pH}$ means the change in $\mathrm{pH}$ from control (5.4 and 8.7 for red clayey and sandy soil solution, respectively); $\Delta$ Eh means the change in Eh from control (184.2 and 18.9 for red clayey and sandy soil solution, respectively). EFS: electric furnace slag, JSF: Japanese Si fertilizer, RSC: rice straw compost, RHB: rice husk-biochar, RHA: rice husk-ash, cacao SB: cacao shell-biochar, MM: media of mushroom.

\subsubsection{Red Clayey Soil}

The mean value of differences $(\Delta)$ during the entire incubation period for soil solution $\mathrm{pH}$ ranged from -0.6 to 2.6 units. Where, the increase in soil solution $\mathrm{pH}$ was 0.2 to 2.6 units. The soil solution $\mathrm{pH}$ was elevated by addition of all the materials, other than silica gel. The lowest soil solution $\mathrm{pH}$ was found in silica gel (4.8) and a maximum increase was obtained in cacao SB (8.0). Among inorganic material, the highest $\mathrm{pH}$ was gained with EFS application (7.2). Soil solution pH with added steel slag, fly ash, RSC and RHA were almost the same (6.1-6.5). Meanwhile, JSF and MM were close in soil solution $\mathrm{pH}$ (6.9 and 6.7, respectively). RHB and elephant grass increased soil solution $\mathrm{pH}$ with almost the same value (5.6 and 5.9, respectively). 
According to Ponnamperuma (1972) that submerging soil cut off oxygen supply, where aerobic organisms use up the oxygen present in the soil. Kashem and Singh (2001) reported oxygen is reduced at Eh $>300 \mathrm{mV}$ and $\mathrm{Mn}^{4+}$ at Eh of $200 \mathrm{mV}$. We observed that Eh decrease with decreasing $\mathrm{pH}$, especially with organic material treatment. Kashem and Singh (2001) reported that organic material had contributed to low and negative values of Eh resulting into higher increase in $\mathrm{pH}$ values.

Decreases in Eh were observed for the soil samples with addition of Si materials after submergence, except for soil with silica gel, where the values rose to $256.5 \mathrm{mV}$. The submerged condition with the addition of steel slag and fly ash result almost the same value of $\mathrm{Eh}$ (155.9 and $140.9 \mathrm{mV}$, respectively). The negative Eh was found in soil solution with RSC, cacao SB, elephant grass and MM (-7.7 to $-91.9 \mathrm{mV})$. We observed RHB and RHA had almost the same in soil solution Eh (171.3 and $161.3 \mathrm{mV}$, respectively), it might be because both material were rice husk.

Even though, steel slag and EFS from steel company but the Eh of soil solution Eh with EFS $(68.0 \mathrm{mV})$ was lower than steel slag. It was probably due to Mn content in EFS was higher that influenced Eh. Whereas, soil solution Eh with JSF application was higher than EFS (100.9 mV), but it was also probably due to high Mn content in original material.

\subsubsection{Sandy Soil}

It is obvious from Table 3 that the increased in sandy soil solution $\mathrm{pH}$ occurred following additions of steel slag, EFS, JSF, RHA and cacao SB with the highest increase of 2.3 units was JFS. Soil pH decreased with addition of silica gel, fly ash, RSC, RHB, elephant grass and MM with incubation time. The largest decreasing -2.3 units of $\mathrm{pH}$ was elephant grass.

Steel slag, EFS, RHA and cacao SB increased pH around 9.4-10.2. Meanwhile, RSC, elephant grass and MM decreased $\mathrm{pH}$ close to neutral (6.4-6.9). Silica gel and fly ash were almost the same in lowering soil solution $\mathrm{pH}$ (8.3 and 8.6, respectively) whereas $\mathrm{pH} 7.8$ in soil solution was obtained with RHB application.

The Eh in soil solution with additional of steel slag, EFS, JSF, cacao SB, elephant grass and MM markedly decreased after submergence and the maximum negative value of $92.8 \mathrm{mV}$ was observed for soil solution with elephant grass application. Elephant grass, cacao SB and MM as organic matter increased microbial activity in sandy soil thus decreasing soil solution Eh.

The Eh change was not as large as observed in red clayey soil. Meanwhile, Eh increased with addition of silica gel, fly ash, RSC, RHB and RHA. The highest soil solution Eh was obtained after added RHB (43.3 mV). Interactive the effect of submergence with RSC, RHB and RHA had the same result, which soil solution Eh was not decrease with those material. The same trend was probably due to the same source from rice plant.

\subsection{Characteristics of Si Release from the Materials}

Generally, soil pH regulates the solubility and the mobility of Si (Tubana \& Heckman, 2015). The Eh of soils controls the stability of various oxidized components such as Mn IV and Fe III in submerged soils (Sahrawat, 2005). Reduction in Eh was accompanied with an increase in the solubility of the soil Si, where Si increase in soil solution was attributed to the release from ferric silica complexes under anaerobic conditions (Ponnamperuma, 1965). This is in line with Snyder et al. (2006) who reported that Si release such as monosilicic acid and polysilicic acid that have high chemical activity can react with Fe in the formation of slightly soluble silicate. Makabe et al. (2013) reported that Si concentration had significantly negative correlation with Ca in soil solution.

Figure 2 revealed some significant correlations between Si release with $\mathrm{Ca}$ or Eh changes for each material. We characterized the materials as below. 

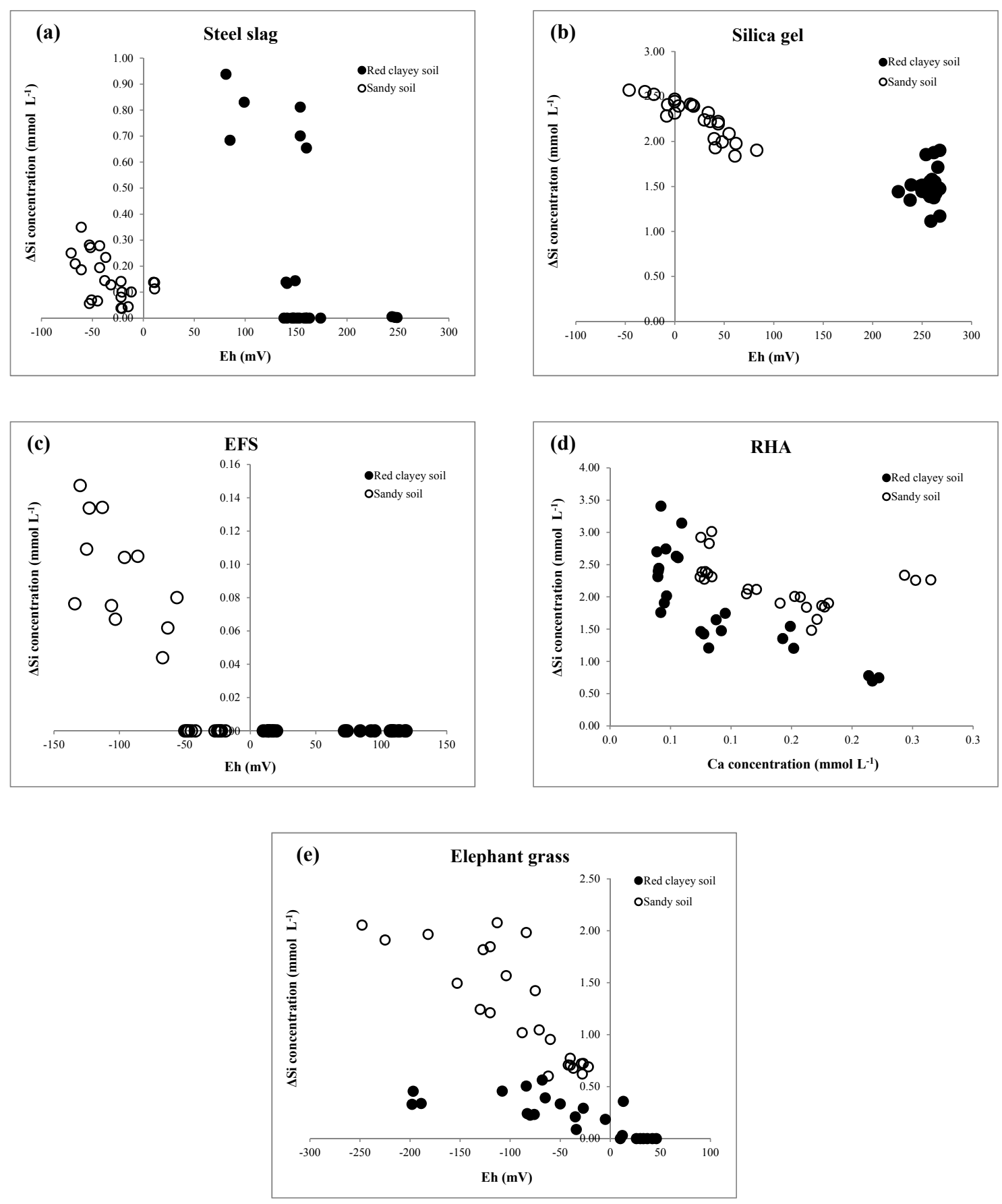

Figure 2. Correlations coefficient of Si concentration from material and other elements in soil solution

\subsubsection{Steel Slag}

Si release from steel slag in red clayey soil showed positive correlation with Fe release and negative one with Eh change in soil solution (Figure 2a). At conditions in which $\mathrm{pH}$ of soil solution was weak alkaline, Si was not affected by $\mathrm{pH}$, but was negatively correlated with Eh. This indicated that Si release of the steel slag was basically controlled by dissolution of the slag with lowering Eh. Steel slag contains Si as calcium silicate form and the slag dissolution and $\mathrm{Si}$ release proceeded by following two steps, i) $\mathrm{Ca}$ and $\mathrm{Mg}$ are dissolved by ion exchange reaction with hydrogen ion in water (first step), ii) Si-O-Si and/or Al-O-Si chemical bonds are cleaved by hydrolysis (second step) (Kato \& Owa, 1996). Kato and Owa (1996) also reported that lowering pH increase Si release and in contrast high Ca content in soil or soil solution decreased it. Beside, Liang et al. (2015) reported 
that low soil Eh at flooding condition, normally leads to an increase in available Si concentration. Lower Eh of sandy soil (Table 1) probably led to release of Si from the beginning of incubation. However, total amount of Si released from the steel slag was higher in red clayey soil, which was due to lower $\mathrm{pH}$ and lower exchangeable $\mathrm{Ca}$ content of the red clayey soil.

\subsubsection{Silica Gel}

Silica gel released highest concentration of Si among all the materials in both acid and weak alkaline conditions. We observed that Si release from silica gel in sandy soil solution condition was higher than in red clayey soil by $40 \%$ (Table 2). It seemed that high $\mathrm{pH}$ and low Eh (Figure 2b) in soil solution increased Si release from silica gel.

\subsubsection{Fly Ash}

Fly ash is made up of highly insoluble, glass-like particles, consisting of amorphous ferro-aluminosilicate and quartz (Haynes et al., 2013). The total amount of Si released from fly ash was higher in red clayey soil, which was due to lower $\mathrm{pH}$ in soil solution (Table 3).

\subsubsection{Electric Furnace slag and Japanese Si Fertilizer}

EFS consist of $\mathrm{CaSiO}_{3} / \mathrm{MgSiO}_{2}$ (Tubana \& Heckman, 2015), where Si release was affected by reduction of Eh and $\mathrm{pH}$ in soil solution. EFS and JSF did not aparently release Si in red clayey soil solution (Table 2), which is possibly due to specific range of $\mathrm{pH}$ and relatively high Eh comparing with sandy soil condition. According to Meyer (1999), Si solubility is lowered at $\mathrm{pH}$ range of 6.5-7.5. Thus, soil pH, 7.2 and 6.9 for EFS and JSF (Table 3 ), respectively in red soil suppressed Si release from the materials.

\subsubsection{Rice Straw Compost}

RSC stably released Si in both soil conditions, although it was higher in sandy soil than in red clayey soil. Exchangeable $\mathrm{Ca}$ and $\mathrm{Mg}$ in red clayey soil might suppress Si release, but exchangeable $\mathrm{Ca}$ or $\mathrm{Mg}$ in sandy soil seemed not to influence the Si release. It was confirmed as an effective soil Si amendment.

\subsubsection{Rice Husk-Biochar and Rice Husk-Ash}

Silicon in rice husk was concentrated and increased in its availability by ashing (Table 1). The release of Si from RHA looked negatively affected by Ca (Figure 2d). Thus, we assume Si in RHA was changed in Ca bind form and $\mathrm{Ca}$ in soil or material itself might suppresse Si release. While Ca did not suppresse Si release from RHB. Eh was a possible factor influencing Si release from RHB as the release of Si was higher with low Eh in sandy soil (Table 3).

\subsubsection{Cacao SB}

The results of this study revealed that there was an inverse relationship between $\mathrm{Ca}$ and $\mathrm{Si}$ concentration in red clayey soil solution. Higher $\mathrm{pH}$ and exchangeable $\mathrm{Ca}$ content in sandy soil tended to reduce Si release from cacao SB. This is more likely because Ca binds $\mathrm{Si}$ in cacao SB which might hardly dissolve under higher $\mathrm{pH}$ and $\mathrm{Ca}$ condition. It seems there is a higher potential to release $\mathrm{Si}$ in acidic and low exchangeable $\mathrm{Ca}$ soil condition.

\subsubsection{Elephant Grass and Media of Mushroom}

Silicon release of elephant grass (Figure 2e) and MM was negatively correlated with Eh change. Elephant grass and MM had relatively high potential to reduce soil Eh but they also enhance release of Fe and Mn especially in red clayey soil (Table 2). Eh of soil control the solubility of Fe and Mn oxides (Patra \& Neue, 2010). Solubilitzation of $\mathrm{Fe}$ and $\mathrm{Mn}$ possibly influence Si release from elephant grass and MM.

\subsection{Prospectives of Local Materials as Silicon Fertilizers}

Most of the land area in Indonesia are acidic soil, of which area is around 102,000,000 ha. The dominant acidic soil types are Ultisols and Oxisols, and some belong to Entisols, Inceptisols and Spodosols (Subagyo et al., 2000; Mulyani et al., 2009). In order to discuss the possibility to use examined materials in the present study for $\mathrm{Si}$ amendments in Indonesian paddy fields, we focused on the results found in red clayey soil as most of the land area in Indonesia are acidic soil. Overall Si materials, release of Si into red clayey soil solution were high for steel slag, cacao SB, RSC and also RHB as local Si materials. These can be candidates of Si amendments of paddy soil in Indonesia. The amount of Si release from EFS, elephant grass and MM were relatively low. Therefore, we assume these materials are not effective to improve paddy soil available $\mathrm{Si}$ in Indonesia. Although silica gel could be of course a good Si fertilizer as it was used in Japan, it is presently expensive for Indonesian local farmers. 
In terms of availability of these materials in Indonesia, steel slag is promising. Rice straw is the biggest waste in Indonesia with the amount of 55 million ton per year (Setiarto, 2013). So far in Indonesia, there has been no research on Si content in rice straw and straw compost. Thus we cannot give recommendation which is better between rice straw and rice straw compost. Generally, agricultural waste in Indonesia is burned to accelerate land preparation. Based on our result that rice straw compost release high $\mathrm{Si}$, thus farmers can sell the rice straw compost to increase income. Furthermore we suggest to make rice straw as compost.

Rice husk is also available throughout Indonesia. For the use of rice straw and husk, it is easy to collect and use in rice producing areas as farmers' groups exist. Besides, its function as Si amendment, i.e. Si release, can be easily improved by burning in paddy fields as the present study exhibited.

Cacao production for some regions in Indonesia such as Sumatera, Java and Sulawesi were 0.36; 0.40 and 0.46 ton $\mathrm{ha}^{-1}$ on 2013 (Tree Crop Estate Statistics of Indonesia, 2014). Cacao shell waste has not been optimally used in Indonesia (Murni et al., 2012), thus its agricutural use is recommendable. Furthermore, we may improve this material by charring to increase available Si in soil.

\section{Conclusions}

EFS, Fly ash and organic materials under submerged condition in paddy fields, improved Si availability. Besides, the addition of local materials such as steel slag reduces the soil Eh. Local materials such as steel slag, rice straw and husk, and cacao shell could be used as Si amendments in paddy fields in Indonesia. Additionally, other materials with relatively low Si release (i.e. elephant grass and MM) could be used to improve the availability Si in soil.

\section{Acknowledgements}

This work was partly supported by Japan Society for the Promotion of Science KAKENHI Grant Number 24405047. The first author gives thanks for the scholarships provided by Indonesian Agency for Agricultural Research and Development. Ministry of Agriculture Republic of Indonesia.

\section{References}

Anonymous. (n.d.). Badan Meteorologi Klimatogi dan Geofisika (BMKG), 2000-2013.

Badan Pusat Statistik (BPS). (2015). Statistics of South Sumatera Province.

Banten. (September 23, 2016). Geographical conditions of Banten province. Retrieved from http://www.bantenprov.go.id

Beckwith, R. S., \& Reeve, R. (1963), Studies on soluble silica in soils. I. The sorption of silicic acid by soils and minerals. Aust J. Soil Res., 1, 157-68. In Liang, Y., Nicolic, M., Belanger, R., Gong, H., \& Song, A. (2015). Silicon in agriculture. From theory to practice (p. 56). Springer Dordrecht Heidelberg New York London. http://dx.doi.org/10.1071/SR9630157

Bunker, B. C., Tallant, D. R., Headley, T. J., Turner, G. L., \& Kirkpatrick, R. J. (1988). Chemistry of glasses (Vol. 29, p. 106). In Kouassi, S. S., Andji, J., Bonnet, J. P., \& Rossignol, S. (2010). Dissolution of waste glasses in high alkaline solutions. Ceramics-Silikaty, 54(3), 235-240.

Cornelis, J. T., Delvaux, B., Georg, R. B., Lucas, Y., Ranger, J., \& Opfergelt, S. (2011). Tracing the origin of dissolved silicon transferred from various soil-plant systems towards rivers: A review. Biogeosciences, 8 , 89-112. http://dx.doi.org/10.5194/bg-8-89-2011

Datnoff, L. E., \& Rodrigues, F. A. (2005). The Role of Silicon in Suppressing Rice Diseases. APSnet Features. http://dx.doi.org/10.1094/APSnetFeature-2005-0205

Dematte, J. L. I., Paggiaro, C. M., Beltrame, J. A., \& Ribeiro, S. S. (2011). Uso de silicatos em cana-de-acucar. Informacoesonomicas (No. 133, pp. 7-12). In Anderson, C. M., \& Lauricio, E. (2013). Silicon: Fertilization and nutrion in higher plants. Amazonian Journal of Agricultural and Environmental Sciences.

Environmental Protection Agency (EPA). (1993). Standard for the use or disposal of sewage sludge (40 CFR Part 257, p. 288).

FAO. (2010). Agricultural commodity projections to 2010.

Flint, E. P., \& Wells, L. S. (1934). Study of the system $\mathrm{CaO}-\mathrm{SiO}_{2}-\mathrm{H}_{2} \mathrm{O}$ at $30 \mathrm{C}$ and of the reaction of water on the anhydrous calcium silicates. Part of Bureau of Standards Journal of Research (Vol. 12). U.S. Department of Commerce. http://dx.doi.org/10.6028/jres.012.060 
Foy, C. D. (1992). Soil chemical factors limiting plant root growth. Adv. Soil Sci., 19, 97-149. In Datnoff, L. E., \& Rodrigues, F. A. (2005). The Role of Silicon in Suppressing Rice Diseases. APSnet Features. http://dx.doi.org/10.1007/978-1-4612-2894-3_5

Gascho, G. J. (2001). Silicon sources for Agriculture. In L. E. Datnoff, G. H. Snyder, \& G. H. Korndorfer (Eds.), Silicon in Agriculture. Elsevier Science, Amsterdam, Netherlands. http://dx.doi.org/10.1016/S0928-3420 (01)80016-1

Hansen, H. C. B., Wetche, T. P., \& Rauland-Rasmussen, K. (1994). Stability constants for silicate adsorbed to ferrihydrite. Clay Minerals, 29, 341-450. http://dx.doi.org/10.1180/claymin.1994.029.3.05

Haynes, R. J. (2014). A contemporary overview of silicon availability in agricultural soils. J. Plant Nutr. Soil Sci., 177, 831-844. http://dx.doi.org/10.1002/jpln.201400202

Haynes, R. J., Belyaeva O. N., \& Kingston, G. (2013). Evaluation of industrial wastes as sources of fertilizer silicon using chemical extractions and plant uptake. J. Plant Nutr. Soil Sci., 176, 238-248. http://dx.doi.org/10.1002/jpln.201200372

Husnain, W. T., Setyorini, D., Hermansah, Sato, K., \& Masunaga, T. (2008). Silica availability in soils and river water in two watersheds on Java Island, Indonesia. Soil Sci. Plant Nutr., 54, 916-927. http://dx.doi.org/10.1111/j.1747-0765.2008.00313.x

Imaizumi, K., \& Yoshida, S. (1958). Edaphological studies on silicon supplying power of paddy fields. Bulletin Natl. Inst. Agric. Sci., Series B(8), 261-304.

Jawa Barat. (September 23, 2016). Retrieved from http://www.jabarprov.go.id

Kashem, M. A., \& Singh, B. R. (2001). Metal availability in contaminated soils: I. Effects of flooding and organic matter on changes in Eh, $\mathrm{pH}$ and solubility of $\mathrm{Cd}, \mathrm{Ni}$ and $\mathrm{Zn}$. Nutrient Cycling in Agronoecosystems, 61, 247-255. http://dx.doi.org/10.1023/A:1013762204510

Kato, N., \& Owa, N. (1996). Dissolution of slags in water and calcium chloride solution: Effects of solution $\mathrm{pH}$ and calcium concentration on solubilities of slags. Jpn. J. Soil Sci. Plant Nutr., 67, 626-632. http://dx.doi.org/ 10.1080/00380768.1997.10414757

Kato, N., \& Owa, N. (1997). Dissolution of slag fertilizers in a paddy soil and Si uptake by rice plant. Soil Sci. Plant Nutr., 43(2), 329-341.

Kendrick, J. K. (2006). Pedogenic silica accumulation. Encyclopedia of soil science (2nd ed., Vol. 2, p. 1251). Taylor and Francis.

Koyama, T., \& Sutoh, M. (1987). Simultaneous multi element determination of soils, plant and animal samples by inductively coupled plasma emission spectrophotometry. Soil Science \& Plant Nutrition, 58, 578-585.

Liang, Y., Nicolic, M., Belanger, R., Gong, H., \& Song, A. (2015). Silicon in agriculture. From theory to practice (p. 45, 58, 230). Springer Dordrecht Heidelberg New York London. http://dx.doi.org/10.1007/978-94017-9978-2

Ma, J. F., \& Yamaji, N. (2006). Silicon uptake and accumulation in higher plants. Trends in Plant Science, 11(8). http://dx.doi.org/10.1016/j.tplants.2006.06.007

Makabe-Sasaki, S., Kakuda, K., Sasaki, Y., \& Ando, H. (2013). Effect of slag silicate fertilizer on dissolved silicon in soil solution based on the chemical properties of Gleysols. Soil Science and Plant Nutrition, 59, $271-277$. http://dx.doi.org/10.1080/00380768.2012.763022

Marafon, A. C., \& Endres, L. (2013). Silicon: Fertilization and nutrition in higher plant. Amazonian Journal of Agricultural and Environmental Science, Rev. Cienc. Agrar., 56(4), 380-388. http://dx.doi.org/10.4322/ rca.2013.057

Marxen, A., Klotzbücher, T., Jahn, R., Kaiser, K., Nguyen, V. S., Schmidt, A., ... Vetterlein, D. (2016). Interaction between silicon cycling and straw decomposition in a silicon deficient rice production system. Plant Soil, 398, 153-163. http://dx.doi.org/10.1007/s11104-015-2645-8

Meyer, P. (1999). Behavior of silica in ion exchange and other systems. Proc. International Water Conf. 64.

Ministry of Energy and Mineral Resouces. (2014). Outlook Energy Indonesia. Ministry of Energy and Mineral Resouces, Republic of Indonesia.

Ministry of Industry Republic of Indonesia. (2014). Profile of steel industry. 
Molina, F. V. (2014). Soil colloids. Properties and ion binding (p. 339). CRC Press. Taylor \& Francis Group.

Mulyani, A., Rachman, A., \& Dariah, A. (2009). Proliferation of acid land, potential and availability for agricultural development. Book of Natural phosphate: Utilization of natural phosphate is used directly as a fertilizer source (pp. 25-46). Indonesian Soil Research Institute, Bogor.

Murni, R., Akmal, \& Okrisandi, Y. (2012). Utilization cocoa pods fermented with phanerochaete chrysosporium as forage substitution in goat feed. Agrinak, 2(1), 6-10.

Patra, P. K., \& Neue, H. U. (2010). Dynamics of water soluble silica and silicon nutrition of rice in relation to changes in iron and phosphorus in soil solution to soil drying and reflooding. Archived of Agronomy and Soil Science, 56(6), 605-622. http://dx.doi.org/10.1080/03650340903192042

Pereira, H. S., Korndorfer, G. H., Moura, W. F., \& Correa, G. F. (2003). Extractors of available silicon in slags and fertilizers. Revista Brasileira de Ciencia do Solo, 27, 265-274. In Haynes, R. J., Belyaeva, O. N., \& Kingston, G. (2013). Evaluation of industrial wastes as sources of fertilizer silicon using chemical extractions and plant uptake. J. Plant Nutr. Soil Sci., 176, 238-248. http://dx.doi.org/10.1590/S0100-06832003000200007

Ponnamperuma, F. N. (1965). Dynamic aspects of flooded soil and nutrition of the rice plant. The Mineral nutrition of rice plant (pp. 295-328). Baltimore, MD: Johns Hopkins. In Tubana, B. S., \& Heckman, J. R. (2015). Silicon in soils and plants. In F. A. Rodrigue, \& L. E. Datnoff (Eds.), Silicon and Plant diseasses. Springer International Publishing Switzerland.

Ponnamperuma, F. N. (1972). The chemistry of submerged soils. Advances in Agronomy, $24,45-51$. http://dx.doi.org/10.1016/s0065-2113(08)60633-1

Rabovsky, J. (1995). Biogenic amourphous silica. Scandinavian Journal of Work, Environ \& Health, 21 (Suppl. 2), 108

Ramenzanianpour, A. A. (2014). Cement replacement materials. Springer Geochemistry/Mineralogy. http://dx.doi.org/10.1007/978-3-642-36721-2_2

Sahrawat, K. L. (2005). Fertility and organic matter in submerged rice soils. Current Science, 88(5).

Savant, N. K., Korndorfer, G. H., Datnoff, L. E., \& Snyder, G. H. (1999). Silicon nutrition and sugarcane production: A review. J. Plant Nutr. 22(12), 1853-1903. In Haynes, R. J., Belyaeva, O. N., \& Kingston, G. (2013). Evaluation of industrial wastes as sources of fertilizer silicon using chemical extractions and plant uptake. J. Plant Nutr. Soil Sci., 176, 238-248. http://dx.doi.org/10.1080/01904169909365761

Savant, N. K., Synder, G. H., \& Datnoff, L. E. (1997). Silicon management and sustainable rice production. $A d v$ Agron, 58, 151-199. In Tubana, B. S., \& Heckman, J. R. (2015). Silicon in soil and plants. In F. A. Rodrigue \& L. E. Datnoff (Eds.), Silicon and Plant diseasses. Springer International Publishing Switzerland. http://dx.doi.org/10.1016/S0065-2113(08)60255-2

Setiarto, R. H. B. (2013). Prospects and potential of rice utilization of lignocellulose into compost, silage and biogas by microbial fermentation. Jurnal Selulosa, 3(2), 51-66.

Snyder, G. H., Matichenkov, V., \& Datnoff, L. E. (2007). Silicon. In A. Barker, \& D. Pilbeam (Eds.), Handbook of Plant Nutrition (Chapter 19, pp. 551-568). Taylor and Francis, Boca Raton, FL.

Subagyo, H., Nata, S., \& Agus, B. S. (2000). Soil-agricultural land in Indonesia. Book of Indonesian land resources and their Management (pp. 21-66). Soil and Agro-climate Research Center, Bogor.

Sumida, H. (1992). Silicon supplying capacity of paddy soils and characteristics of silicon uptake by rice uptake in cool regions in Japan. Bull. Tohoku. Agric. Exp. Stn, 85, 1-46.

Tree Crop Estate Statistics of Indonesia. (2014). Cocoa 2013-2015. Directorate General of Estate Crops.

Tubana, B. S., \& Heckman, J. R. (2015). Silicon in soils and plants. In F. A. Rodrigue, \& L. E. Datnoff (Eds.), Silicon and Plant diseasses. Springer International Publishing Switzerland. http://dx.doi.org/10.1007/ 978-3-319-22930-0_2

Wei, C. F., Yang, J. H., Gao, M., Xie, D. T., Li, Q. Z., Li, H. L., ... Xiang, T. C. (1997). Study on availability of silicon in paddy soils from purple soil. J. Plant Nutr Fertil., 3, 229-36. In Liang, Y., Nicolic, M., Belanger, R., Gong, H., \& Song, A. (2015). Silicon in agriculture. From theory to practice (p. 58). Springer Dordrecht Heidelberg New York London. 
Xiao, X., Chen, B., \& Zhu, L. (2014). Transformation, morphology and dissolution of silicon and carbon in rice straw derived biochars under different pyrolytic temperatures. Environ. Sci. Technol., 48, 3411-3419. http://dx.doi.org/10.1021/es405676h

\section{Copyrights}

Copyright for this article is retained by the author(s), with first publication rights granted to the journal.

This is an open-access article distributed under the terms and conditions of the Creative Commons Attribution license (http://creativecommons.org/licenses/by/4.0/). 